\title{
O problema do Café no Brasil
}

\section{Antonio Delfim Netto ${ }^{1}$}

É com enorme alegria e gratidão que venho a esta ilustre reunião de economistas, para celebrar um trabalho sexagenário sobre o problema do café no Brasil. ${ }^{1}$ É difícil entender hoje, quando o valor das exportações de café representa cerca de $2 \%$ do total, e uma variação de seus preços têm efeito desprezível sobre nossa capacidade de importar, qual era a importância do problema nos primeiros anos da década dos sessenta do século passado, quando representava mais de $50 \%$ e a mesma variação tinha consequências dramáticas sobre ela, sobre a nossa taxa de câmbio e sobre o nosso crescimento econômico.

Naquele tempo, "café era câmbio", como ensinou o nosso grande mestre, Eugênio Gudin. As variações dos seus preços produziam flutuações internas de grande amplitude e incertezas insuperáveis para as outras atividades domésticas e para as incipientes atividades exportadoras de outros produtos agrícolas. E, muito mais, sobre a nossa, ainda em gestação, atividade industrial.

Como a demanda de café mundial é inelástica e o Brasil controlava mais de $80 \%$ da produção mundial, sua variação produzia efeitos amplificadores na disponibilidade de moeda estrangeira e modificações devastadoras na taxa de câmbio. Nessa época, a política cafeeira era parte da grande preocupação com o desenvolvimento do Brasil que reinava na FEA. Atenção também era dedicada à análise da agricultura que alguns acreditavam ser um setor arcaico que não reagia aos movimentos do mercado. Ela era tida como responsável pela inflação.

1 Professor Emérito - Universidade de São Paulo - Endereço: Av. Professor Luciano Gualberto, 908 Butantã - São Paulo/SP - Brasil - CEP: 05508-010 - E-mail: ideias.consult@uol.com.br. ORCiD: https://orcid.org/0000-0001-7365-242X.

Editor Responsável: Dante Mendes Aldrighi

(c) (i) (\$) Esta obra está licenciada com uma Licença Creative Commons Atribuição-Não Comercial 4.0 Internacional. 
O problema que o Brasil resolveu foi o de reduzir a importância relativa do café na geração de divisas, fazendo a cafeicultura crescer, ao mesmo tempo, internamente em termos absolutos. Ao contrário do que se supõe, uma política de crawling peg (combinada com a tributação das exportações de café) permitiu, entre 1966 e 1973, uma abertura da economia e estimulou as exportações (20\% ao ano), as importações (25\% ao ano) e reduziu a relação Dívida Externa/Exportação, de 1,9 para 1,4, enquanto a inflação caía (IGP-DI, FGV) de 39\% para 16\% ao ano.

De fato, entre 1967 e 1980, as exportações brasileiras de manufaturados com relação às exportações mundiais de manufaturados cresceu $15 \%$ ao ano. Há poucas dúvidas de que a indústria brasileira no limiar dos anos 80 do século passado era das mais sofisticadas do mundo emergente, como reconhece o Banco Mundial.

Os anos 50 do século passado foram turbulentos na FEA/USP porque se tentava recuperar um esforço elogiável de sua primeira geração de professores escolhidos politicamente. A maioria era profissionalmente competente em suas áreas, mas muito distantes da disciplina que lhe deu o nome. As exceções mais notáveis foram o ilustre professor Paul Hugon, que nos mostrou a importância da história do pensamento econômico, e o grande professor Wilfred Leslie Stevens, que introduziu entre nós a então moderna estatística fisheriana.

Tinha havido uma intervenção do Conselho Universitário por pressão dos alunos e foi nomeado diretor o ilustre Ruy Aguiar da Silva Leme, uma das mais brilhantes inteligências com a qual tive a honra de conviver. Ele começou a organizar alguns concursos e a grande historiadora, Alice Pfiffer Canabrava, foi aprovada com louvor e alegria de toda a FEA, no primeiro deles.

No início de 1960, sob a liderança do ilustre professor Luiz de Freitas Bueno, estudamos Karl Popper, o que iluminou os angustiados. Capturou corações e mentes, e convenceu-nos que lá estava a "verdade": qualquer proposição - pelo método científico - nunca será provada, mas poderá ser rejeitada pelo exercício empírico. O estatuto científico de uma teoria era a possibilidade de sua falseabilidade. Bueno já tinha tido acesso a um artigo de Popper, sobre o assunto, de 1953.

1 café no Brasil (Delfim Netto, 1959) 
A professora Canabrava já usava, intuitivamente, o critério: história apoiada em boas narrativas sustentadas pela pesquisa empírica (fatos quantificáveis; testamentos, anúncios em jornais de compra e venda de escravos, custo de transporte, etc.) que as sustentavam. Ela chegou a usar como assessor estatístico, o ilustre professor Affonso Celso Pastore. Aliás, este usou o mesmo protocolo na sua importante tese sobre o comportamento dos agricultores brasileiros diante dos estímulos monetários produzidos pelo mercado.

Muitas das teses da FEA publicadas posteriormente sempre combinaram História, boas narrativas quantitativas, Teoria Econômica para construir "modelos" analíticos quantificáveis e Econometria, para tentar rejeitá-los, aplicados a problemas relevantes para o desenvolvimento social e econômico do Brasil.

\section{Referência}

1. Delfim Netto, A. (1959). O Problema do Café no Brasil. Editora UNESP, terceira edição, 2009. 